\title{
BELINDA RUDINGER*
}

Commerce, USA

ORCID ID: https://orcid.org/oooo-0002-5253-0391

\section{NON-VISUAL ACCESS TO PRINT \& ITS BARRIERS. A REVIEW OF THE LITERATURE}

\begin{abstract}
This literature review examines the multiple barriers to non-visual access to print by people who are blind. An in-depth consideration of existing research on specific issues related to screen readers and refreshable braille displays is provided. These barriers include the complexities involved in the conversion of print to alternate media (tactual and auditory), assistive technology instruction and readiness of teachers of students with visual impairments, lack of research on best practices for instruction, and a variety of issues related to technological constraints in the areas of accessibility, usability, and user experience. Recommendations for practice and future research in the areas of screen readers and refreshable braille displays are included.
\end{abstract}

Keywords: assistive technology; access; blind; usability; user experience; braille; visual impairment; screen reader; refreshable braille display.

\section{Introduction}

Breaking down the barriers between blind people and print involves examining an entangled series of issues that are numerous and complex. Individuals who are blind rely on technology to enable nonvisual access to print. Historically, print has typically been mediated by other humans for this particular population; only in recent times of ubiquitous technology use in the mainstream has this shifted

* Dr. Belinda Rudinger, Ed.D., ATP, President-Elect, Texas AER, Adjunct Faculty, Department of Psychology \& Special Education, Texas A\&M University, Commerce, USA; e-mail: belinda. rudinger@tamuc.edu. 
to technological mediation and direct access. As our world becomes increasingly global and interconnected, inequities between societies and individuals are more evident than ever. When adaptations to print through braille or assistive technology are not provided, inequalities remain.

Complexity, lack of training, and technological issues interfere with access, usability, and user experience. As the technological workflows of non-visual users are different from those of visual users, educators may find such approaches counter-intuitive. While accessibility is gaining awareness in today's society, a focus on "normative" accessibility without considering other aspects such as usability and user experience can lead to additional exclusion. My intent in this paper is to review three common barriers: the complexity of print conversion, the intricacies of providing assistive technology, and issues pertaining to assistive devices themselves (screen readers and refreshable braille displays). In doing so, I hope to highlight how a clearer understanding of these user pathways can assist practitioners in teaching the necessary skills, as well as identifying avenues of future research.

\section{Barrier \#1: The Complexity of Converting Print to Other Modalities}

While assistive technology has allowed for progress, there remain many barriers to print for people with visual impairments, which impacts their ability to access information. At its core, the problem of barriers between blind people and print involves the manipulation of print materials into tactual and auditory access. This involves specialized knowledge and equipment such as braille translation software, braille embossers, software to create tactile graphics, optical character recognition software, and math translation software. The technology and methods exist, but the right information and equipment has to be available to a person with training in adequate time for translation. Godfrey \& Loots (2015) describe how one of the most challenging burdens placed upon students who are blind is accessing the same materials as their classmates (p. 15). Material is frequently unavailable, inaccessible, or requires lengthy wait times that put students at a disadvantage.

The first source of complexity is the original source material. Source material can originate in electronic or paper form. Paper form can be re-typed into electronic form by a human, or be scanned electronically into digital form, but this is more complicated than one might guess. An example includes desktop publishing that mixes text and graphics in layouts designed to be visually interesting (but technically complex for screen readers). Scans generate basic Portable Document Format files (PDF) or Joint Photographic Expert Group files (JPEG), neither of which are directly readable by braille translation programs or screen readers (a screen reader is a software program that allows blind people to use computers, smartphones, or tablets by vocalizing print, menus, and options.) Source material that originates digitally can either be "born accessible" by originating in an easy to use format such as text files, or Word documents without much formatting (Benetech, n.d.). 
It may also be in a PDF and will require the use of optical character recognition (OCR) software (which requires an additional software program, training, and adds a step to the process, thereby extending the time.) Excessive pictures or columning can make this process longer and more complicated, and any graphics will need to be created using different software specific to that task and re-integrated into the electronic file or embossed separately. Once the text has been extracted using either a born accessible document or an OCR program, it can be opened with a braille translation program and translated into a BRF file and embossed or read on an electronic braille notetaker. As Godfrey \& Loots state (2015, p. 15), PDFs are often not fully accessible and require some "post-processing by a human" in order to sure materials are correct.

A second source of complexity in source material involves the production of math and graphics. Regarding the heavy use of graphics in statistics and math courses, Godfrey and Loots add, "The ability of a blind person to read a tactile image is also very dependent on the quality of the image being created and is therefore open to an extra layer of interpretation as the printed picture is converted by a subjective human process into a tactile image" (2015, p. 11). Different countries use different braille codes for math (such as Nemeth code or Unified English Braille math) (Holbrook \& MacCuspie, 2010). Not all assistive devices are equipped to handle either, much less both. The two current options for math production of materials for students includes six key entry whereby teachers or braille transcribers have memorized the math code and type it in braille directly, or additional software that can be used in conjunction with braille translation software to handle math. Graphics are up to the discretion of the intermediary producer of documents. They can be handled though omission, text description, or specialized software programs. There are also complex standards for production but little support or training in their use, which leads to errors in braille and document production (Herzberg, 2010).

While it may initially appear that the task at hand is simply to convert items written in print into alternate modalities such as auditory or tactual (braille), these transpositions involve their own complexities. A case study from Harshman, Bretz, \& Yezierski (2013) illustrates how multiple sources of multi-modal information compete for a student's attention during a college chemistry course:

For a sighted student, the lecturer elaborates on a PowerPoint presentation (auditory input) for the student to sync with the images and text displayed on a slide (visual input), while the student outputs information into the form of working on an exercise or taking notes (tactile). Thus, a student with sight gathers information via two modalities (auditory and visual) and ought to be able to switch between multiple sources of information competing for one modality of input. In contrast Fantine listened to the instructor (auditory input), had the PowerPoint slides translated to Braille (tactile input) or read 
by JAWS (second auditory input), experienced raised images (second tactile input) while the TA explained them to her (second or third auditory input), and then took any notes or works exercises by typing on the Braillenote (tactile output) (p. 711).

A comparison of the strengths and weaknesses of the visual, auditory, and tactual modalities is illustrated in Table 1.

Table 1. Comparison of sensory modalities

\begin{tabular}{|c|c|c|}
\hline Visual & Auditory & Tactual \\
\hline $\begin{array}{l}\text { Organized spatially (up/ } \\
\text { down, left/right)* }\end{array}$ & Organized sequentially* & $\begin{array}{l}\text { Organized spatially (up/down, } \\
\text { left/right)* }\end{array}$ \\
\hline $\begin{array}{l}\text { Can absorb new informa- } \\
\text { tion faster than auditory or } \\
\text { tactual }^{\star * *}\end{array}$ & $\begin{array}{l}\text { Organized temporally; } \\
\text { Primary relationship is time } \\
\text { "Fleeting, sequential, and } \\
\text { a function of time"***}\end{array}$ & Organized temporally* \\
\hline \multirow{3}{*}{$\begin{array}{l}\text { Allows users to quickly filter } \\
\text { out irrelevant, redundant, or } \\
\text { repetititive information }{ }^{\star *} \text {, } \\
\star \star \star\end{array}$} & $\begin{array}{l}\text { Information is serialized and } \\
\text { made linear }\end{array}$ & $\begin{array}{l}\text { Ideal for repeated } \\
\text { information }^{* * *}\end{array}$ \\
\hline & $\begin{array}{l}\text { May allow users to be easily } \\
\text { distracted }^{* * *}\end{array}$ & \\
\hline & $\begin{array}{l}\text { Can be difficult to use for } \\
\text { memorization }^{* * *}\end{array}$ & \\
\hline
\end{tabular}

* Cook \& Polgar, 2015 ** Giraud, Therouanne, \& Steiner, $2018^{\star * \star}$ Buzzi, Buzzi, Leporini, \& Mori, $2012^{* * * *}$ Lazar 2019

Given the differences between the three sensory channels shown in Table 1, Buzzi et al. (2012) contend that "it is necessary to explore multiple routes to equivalent experience" (p. 126). Individual preferences and aptitudes play a role, as well. As stated by Shinohara \& Tenenberg (2009),

Simply replacing one interaction mode, such as the display of text on a screen with a functionally equivalent mode, as in speaking the text aloud, is not necessarily equivalent from the point of view of user experience. This is because functional equivalence might not account for the meaning of the mode of interaction for particular users in specific contexts (p. 66).

Users may have different preferences for transposition in different contexts. Decisions about workflow efficiency and preference are complex, and depend upon individual, context, and task. Care should be taken to transpose materials with this in mind, rather than relying on assumptions of equivalence between sensory modalities in different contexts. 


\section{Barrier \#2: The Complexity of Teaching Assistive Technology}

Alongside the issues of source material and braille translation of literary, math, and graphics, an additional source of complexity is found in the programs, applications, and devices students use to access information. Teaching students to use these devices is a lengthy process and comprises large responsibility for the TVI--one for which he or she may feel ill equipped (Siu \& Emerson 2017; Zhou et al. 2012). Sighted teachers teach complex workflows that they themselves do not use, may not have been taught, and perhaps find counter-intuitive.

The explosion of not only instructional and assistive technologies, but mainstream technology within the past two decades has changed the landscape quickly. Abner \& Lahm (2002) first noted a lack of teacher readiness to teach assistive technology. Smith et al. (2009) used a focus group of 30 experts to develop 111 Assistive Technology competencies for TVIs. The following skills relate to nonvisual access to information:

C63. Teach students with visual impairments the use of AT for access to information in the classroom.

C64. Teach students with visual impairments to produce files in a readable format, including braille, large print, or an electronic form.

C65. Teach students problem-solving techniques for the use of AT in the classroom when materials are not in an accessible format.

C66. Teach students with visual impairments to use the Internet.

C67. Teach students with visual impairments to transfer files to appropriate AT devices.

C68. Teach the student to stay current with new technology, access online manuals, and obtain technical assistance from vendors.

C69. Identify and use a variety of sources for braille materials.

$\mathrm{C} 7 \mathrm{O}$. Identify and use a variety of sources for electronic and recorded materials.

$\mathrm{C}_{71}$. Identify and use a variety of options for accessing information presented on chalkboards, whiteboards, DVDs and other video sources, overhead projectors and computer projector systems.

C73. PC computer and MacIntosh computer accessibility options (universal options menu, accessibility wizard, and display settings) for individuals with visual impairments.

Multiple surveys of TVIs indicated a lack of confidence in their ability to teach AT to their students (Zhou et al., 2011, Zhou et al., 2012). The authors recommend that university personnel preparation programs offer a course on assistive technology, and that AT competencies should be embedded within other curricula. KameiHannan et. al (2012) found an increase in perceived confidence after taking AT coursework professional development. Kelly \& Kapperman (2018) reference the 
creation of a new national certification, Certified Assistive Technology Instructional Specialist (CATIS). Siu (2015) demonstrated that following professional development with an informal virtual community of practice was a successful way to extend and enhance their learning and practice in the area of AT.

A review of evidence-based practices done by Ferrell, Bruce, \& Luckner indicated that there is only limited research in the area of AT for students with visual impairments; what exists is limited to product reports and case studies, and AT is not well implemented (Ferrell et al., 2014). Potential causes may include lack of course work or professional development in AT, the complexity of knowledge needed (Smith et al., 2009), the changing landscape of technology, and the fact that a TVI's caseload dictates experience with different populations using different devices. The ubiquity of instructional and assistive technology ensures an everpresent learning curve (Siu, 2015).

Ajuwon et al. (2016) recommended an increased collaboration, more pre-service and in-service AT training for TVIs, and more hands-on access to devices and programs, as well as research on "the beliefs and opinions of students themselves." (Ajuwon et al., 2016, p. 133).

Jones, Rudinger, Williams, \& Witcher (2019) gave pre-service teachers a hands-on experience with a variety of AT options, including 20 of the original 111 competences. Results indicated that the guided hands-on exploration of AT improved the preservice teachers' perceptions of their own abilities to use AT with students in the future (Jones et al., 2019).

Siu and Emerson (2017) cast the TVI in a new role as Accessibility Facilitator. While provision of accessible instructional materials formerly involved embossed braille and tactile graphics, rapid changes of recent years in instructional technology and delivery have led to changes in "timely and equitable access to information for students with visual materials, how these materials are delivered, and the availability of mainstream and specialized tools" (Siu \& Emerson, 2017, p. 593). They further note that content-area teachers are now more likely to create their own materials than use the state adopted textbooks, as well using online materials that may unintentionally present digital accessibility barriers.

This shift requires that TVIs employ a broader skill set in their collaboration with not only general education teachers, but book publishers, assistive technology departments, instructional technology departments, administrators, and more. Siu and Emerson describe a "digital workflow" as "the design and delivery of digital-only materials which, when accessible, empowers a student to independently interact with information using any preferred sensory learning channel (visual, auditory, or tactile) at any given time" (2017, p. 594). Advocating for the detailed and often oblique needs of this low incidence population means also accurately identifying and clearly explaining potential barriers to a network of involved people (Siu \& Emerson, 2017). Supporting TVI growth into this new role highlights 
once again, the need for more pre-service AT training, AT-related professional development, and AT communities of practice.

\section{Barrier \#3: Accessibility, Usability, \& User Experience}

As technology has evolved, the landscape of access to the written word continues to change for blind people who are braille readers. New technological possibilities are entangled with new barriers. Changes in technology have changed print itself, which has specific ramifications for non-visual users. For example, the original screen reader, Job Access With Speech (JAWS), released for MS-DOS in 1989, pre-dated websites and other current educational applications. Mac's screen reader, VoiceOver, was released in 2005; it was the first time a screen reader was built into an operating system's ecosystem (not only in computers, but later in iOS devices). NonVisual Desktop Access (NVDA) was created by 2 blind users in 2006 and is the only free, open source option for Windows. The iPhone came out in 2007, but did not include a screen reader until 2009. In 2015, the release of Windows 10 included Cortana and Narrator, which provide additional options in speech recognition and text to speech features. Today, the primary assistive technology tools for non-visual access include screen readers (both computer-based and mobile) and refreshable braille displays.

Screen readers are used daily for purposes of school, work, and personal use on both computers and mobile devices (Lazar 2019; McCarthy et al., 2013). Kelly and Kapperman (2018) recommend that before graduating high school, students who are blind should have "mastered the intricacies of at least two screen reading programs" including "all keystroke commands to be able to function expertly" (p. 388). According to the WebAim 8 annual screen reader survey $(n=1224,930)$, $62 \%$ rated their screen reader proficiency as advanced, $32 \%$ as intermediate, and $5 \%$ as beginner (WebAim 2019). $86 \%$ of respondents reported using a screen reader on a mobile device or tablet, $84 \%$ on a laptop, and $68 \%$ on a desktop. $40.6 \%$ of users used NVDA primarily, 40.1\% used JAWS, and 13\% used VoiceOver as their primary computer based screen reader.

Mobile screen readers are also in regular use; $71 \%$ of respondents used VoiceOver, while 33\% used TalkBack (WebAim 2019). Students in a focus group actually indicated a preference for mobile screen readers, sharing that "when you use the computer, there are so many different commands, different shortcuts, ...on the smartphone you find things more easily" (Della Librera \& Jurburg, 2017, p. 250). Leporini, Buzzi, and Buzzi (2012) studied the user experience of interacting with mobile devices using a combination of gestures and the native VoiceOver screen reader. Results showed that the main usability issues were focus handling, logical navigation when items were expanded, and lack of clarity with interactive elements (Leporini, Buzzi, \& Buzzi, 2012). 
Several studies in the field of human-computer interaction examine the user experience of screen readers. A primary theme from the UX research within the HCI field is that access to content is actually just the entryway to the path toward using technology in meaningful ways. Initial access can be a dead end without usability. Buzzi et al. (2010) distinguished accessibility as a prerequisite, while usability opens the door to efficient interaction. Giraud et al. (2017) added that accessibility must be combined with usability; providing access to content is not enough. Lazar (2007) noted that even an accessible program or website can still be inefficient and difficult to use with a screen reader. Describing their individual case study with 'Sara', Shinohara and Tenenberg (2009) add:

Although JAWS increases her access to her computer, many interaction issues remain...One of the biggest challenges of using a screen reader is orientation and navigation. If Sara moves to another task or accidentally hits the wrong hot key, she might find herself in an unfamiliar virtual setting that requires her to suspend the current task, reorient herself, then resume where she left off (p. 63).

Giraud et al. (2018) further describe orientation issue from a user experience perspective:

When I use CTRL + F it is like you want to get the salt from the table and somebody takes your hand and gets the salt, then you would not know what else is on the table and what is around it, etc., if the black pepper is next to it and you need that, you wouldn't know. You have to ask that person to take your hand again. It is exactly what is happening here (p. 31).

Table 2 highlights a number of additional common usability issues from UX research.

Table 2. Usability Issues

\begin{tabular}{|l|l|}
\hline Issue & \\
\hline No overall perception of the entire interface & (Buzzi et al., 2012) \\
\hline Screen reader mixes up content and structure while reading & (Buzzi et al., 2010) \\
\hline $\begin{array}{l}\text { Users must filter out repetitive/irrelevant information (from refreshed } \\
\text { links, duplicate menus, etc.) }\end{array}$ & $\begin{array}{l}\text { (Giraud et al., 2018; } \\
\text { Lazar et al., 2007) }\end{array}$ \\
\hline Serialization of content and text & $\begin{array}{l}\text { (Buzzi et al., 2012; } \\
\text { Giraud et al., 2018) }\end{array}$ \\
\hline $\begin{array}{l}\text { Screen reader may read in incorrect order (reading a table by columns } \\
\text { instead of rows) }\end{array}$ & (Buzzi et al., 2012) \\
\hline
\end{tabular}




\begin{tabular}{|c|c|}
\hline Issue & \\
\hline $\begin{array}{l}\text { Cursor "focus" can either be in editing mode (within a container where } \\
\text { text entry is possible) or exploration mode (where the cursor or arrow } \\
\text { is focused on announcing or activating links, labels, or other functional } \\
\text { areas). }\end{array}$ & (Buzzi et al., 2010) \\
\hline $\begin{array}{l}\text { Users miss spelling suggestions when navigating at a different heading } \\
\text { level }\end{array}$ & (Sahib et al., 2012) \\
\hline $\begin{array}{l}\text { Users ignore internet search suggestions because they would require } \\
\text { navigating away from the search box }\end{array}$ & (Sahib et al., 2012) \\
\hline $\begin{array}{l}\text { Banners at the top of websites disrupt the focus of the screen reader, } \\
\text { which users experience as losing their place }\end{array}$ & $\begin{array}{l}\text { (Craven \& Brophy, } \\
\text { 2003; Sahib et al., } \\
\text { 2012) }\end{array}$ \\
\hline $\begin{array}{l}\text { Users have to construct their own mental models, especially when rela- } \\
\text { tionships or connections between pages or sections is not clear }\end{array}$ & $\begin{array}{l}\text { (Craven \& Brophy, } \\
\text { 2003). }\end{array}$ \\
\hline $\begin{array}{l}\text { Screen reader users took longer than visual users to complete the same } \\
\text { tasks, because they used a higher number of keystrokes per task than } \\
\text { visual users (they took } 16 \text { keystrokes for every } 6 \text { keystrokes/clicks of } \\
\text { a visual user) }\end{array}$ & $\begin{array}{l}\text { (Craven \& Brophy, } \\
\text { 2003). }\end{array}$ \\
\hline
\end{tabular}

In addition to using a screen reader with either a computer or a mobile device, $33 \%$ users also reported use of a refreshable braille display (WebAim 2018). A refreshable braille display (RBD) is an "electromechanical device to display braille dot patterns through small rounded pins that are raised and lowered through holes in the cell surface" (Aranyanak \& Reilly, 2012). These devices, with between 12-80 braille cells, must typically be paired with a smartphone, tablet, or computer running screen reader software, unless embedded within a specific assistive device, called a braille notetaker. Most RBDs include a keyboard, either QWERTY or six key braille entry.

In human-computer interaction research, $\mathrm{RBD}$ s have not been included in studies regarding screen readers; authors reference their high cost as the reason for excluding them (Buzzi et al., 2012; Lazar et al., 2007; McCarthy et al., 2013.) However, several educational studies examine RBD use and highlight their promise.

Kelly and Kapperman (2018) recommended that blind students should have the ability to connect refreshable braille displays to computers, tablets, and smart phones because their use "alleviates the need for large amounts of hard copy braille" (p. 390). Hong (2012) described multiple advantages of using a refreshable braille display. Bickford and Falco (2012) compared embossed braille to refreshable braille, as well as comparing a manual braillewriter with an electronic braille keyboard \& display paired with speech support. Six of seven students preferred the electronic option for writing braille; they enjoyed the auditory feedback option for catching errors as well as keys that were easier to push, no need for paper loading, and the ability to make corrections. (Bickford \& Falco, 2012). A majority preferred the electronic option for reading braille; the plastic refreshable dots were easier to distinguish by touch than embossed braille, and they could pan back and forth between lines (Bickford \& Falco, 2012). D’Andrea (2012) found that students aged 
16-22 valued auditory access over braille because of speed, they appreciated the searching and indexing functions within technology, and they preferred to write electronically using word processing software on computers or braille notetakers. They strongly preferred embossed braille to RBDs specifically for foreign languages, science, and math (D'Andrea, 2012). D'Andrea (2012) underscored the importance of students having multiple devices and options. Kapperman, Koster, and Burman (2018) outlined use of an RBD with the screen reader JAWS for foreign languages. Rudinger (2020) found positive correlations between RBD use and formal training, being coached by a friend, trading tips with fellow users, using online handouts, and using a computer for recreation.

\section{Discussion}

While current research clarifies common issues with screen readers, no studies were found describing common or best practices for instruction in the use of screen readers or refreshable braille displays. While the importance of screen readers is well established and initial studies on refreshable braille displays highlight their potential, there exists no guidance for best instructional practices or most efficient workflows. The impact of pairing an RBD with a screen reader across various tasks has not been investigated. No research has been conducted comparing the efficiency, usability, or user experience of the three primary screen readers: NVDA, JAWS, and VoiceOver. Screen reader proficiency has been linked to users' self-rated competence, a key component of self-determination (Rudinger, 2020). There remains much more to examine regarding non-visual access to print through technology.

Lazar (2019) recommended researching how to convert common screen reader speech output rates to words per minute (WPM) in order to establish a baseline and comparison rate for future studies. This would allow comparison of reading rates (visual, auditory, and braille) which would help understand efficient workflows and best practices. Rudinger (2020) recommended:

Researchers should investigate effective training and instructional methods for teaching non-visual access to print, whether through screen reader software, tactual means such as braille, or multi-modal combinations of access... there is a need for further research to identify evidence-based practices and interventions for efficient and targeted instruction. Researchers could use ethnographic methods such as video and screen recordings to develop case studies of the workflows of power users of screen reader software, potentially offering common attributes and practices of efficient access. Common, but different, screen reader software packages could be compared and contrasted, such as Job Access With Speech (JAWS), Non-Visual Desktop Access (NVDA), and VoiceOver. Focus groups of highly proficient users of each screen reader option could also be employed to further sketch out the details of proficient 
user experience to aid in developing best practices. Single subject research designs could be employed to demonstrate differences between potential instructional interventions and their effectiveness (p. 97-98).

While the field of education has little AT research regarding efficient workflows and best instructional practices for screen readers, Table 3 summarizes some lessons from UX research that can be applied in education.

Table 3. Strategies \& recommendations based on UX research

\begin{tabular}{|l|l|}
\hline For teaching students & For training TVIs \\
\hline $\begin{array}{l}\text { Provide tactile outline or overview of content } \\
\text { to accompany auditory version (Buzzi et al., } \\
\text { 2012) }\end{array}$ & $\begin{array}{l}\text { Create schematics of websites or computer } \\
\text { programs with functional areas labeled (exam- } \\
\text { ples in Buzzi et al. 2010) }\end{array}$ \\
\hline $\begin{array}{l}\text { Use landmark items, memorize menus and } \\
\text { layout } \\
\text { (Kim et al., 2016) }\end{array}$ & $\begin{array}{l}\text { Pair a picture of a screen with a script listing } \\
\text { the exact statements announced by the } \\
\text { screen reader (examples in Buzzi, Leporini, \& } \\
\text { Meattini, 2018) }\end{array}$ \\
\hline $\begin{array}{l}\text { Write down search process when interacting } \\
\text { with websites so that steps can be retraced } \\
\text { (Sahib et al., 2012) }\end{array}$ & \\
\hline $\begin{array}{l}\text { Explicitly teach structure of the internet and } \\
\text { its unpredictability \& common issues: no } \\
\text { alt-text, inaccessible PDFs, confusing page } \\
\text { layouts, conflicts between screen readers and } \\
\text { applications, and unlabeled or misleading } \\
\text { forms and links (Lazar et al., 2007). }\end{array}$ & \\
\hline
\end{tabular}

Promoting non-visual access to print through technology involves a full understanding of potential barriers. This understanding will allow practitioners to consider fully both the technical complexity of converting text and the importance of considering differences between sensory modalities when transposing content for different individuals, tasks, and settings. TVIs can better assume responsibility for AT instruction and serving the role of Accessibility Facilitator when given coursework and professional development in AT that is followed up by participation in communities of practice. An awareness of not only accessibility, but also potential issues and solutions related to the usability and user experience of screen readers can help users maximize their potential efficiency. As technology continues to evolve, these and other issues will continue to be important conversations in the ongoing improvement of nonvisual access. 


\section{References}

Abner, G., \& Lahm E. (2002). Implementation of assistive technology with students who are visually impaired: Teachers' readiness. Journal of Visual Impairment \& Blindness, 96(2), 98-105.

Ajuwon, P., Griffin-Shirley, N., \& Okungu, P. (2016). Reflections of teachers of visually impaired students on their assistive technology competencies. Journal of Visual Impairment \& Blindness, 110(2), 128-134.

Aranyanak, I., \& Reilly, R. (2013). A system for tracking braille readers using a Wii Remote and a refreshable braille display. Behavior Research Methods, 45(1), 216-228.

Benetech (n.d.). Born Accessible. https://benetech.org/our-work/born-accessible/

Bickford, J., \& Falco, R. (2012). Technology for early braille literacy: Comparison of traditional braille instruction and instruction with an electronic notetaker. Journal of Visual Impairment \& Blindness, 106(10), 679-693.

Buzzi, M.C., Buzzi, M., Leporini, B., Mori, G., \& Penichet, V. (2010). Accessing Google Docs via screen reader, ICCHP, 92-99.

Buzzi, M.C., Buzzi, M., Leporini, B., \& Mori, G. (2012). Designing e-learning collaborative tools for blind people. In E. Pontes (Ed.), E-learning: long-distance and lifelong and perspectives (125-145). Sao Paolo: Intech Open.

Buzzi, M., Leporini, B., \& Meattini, C. (2018). Simple smart homes web interfaces for blind people. Proceedings of the 14th International Conference on Web Information Systems and Technologies, Seville (223-230). Retrieved from: https:// www.scitepress.org/Link.aspx?doi=10.5220/ooo6935602230230.

Cook, A.M., \& Polgar, J.M. (2015) Assistive technologies: Principles and practice. St. Louis: Elsevier.

Cook, B.G., \& Odom, S.L. (2013). Evidence-based practices and implementation science in special education. Exceptional Children, 79(2), 135-144.

Craven J., \& Brophy, P. (2003). Non-visual access to the digital library (NoVA): The use of the digital library interfaces by blind and visually impaired people. Library and Information Commission Research Report (1) 45. Centre for Research in Library and Information Management.

D'Andrea, F.M. (2012). Preferences and practices among students who read braille and use assistive technology. Journal of Visual Impairment \& Blindness, 106(10), 585-596.

Della Líbera, B., \& Jurberg, C. (2017). Teenagers with visual impairment and new media: A world without barriers. British Journal of Visual Impairment, 35(3), 247-256.

Ferrell, K.A., Bruce, S., \& Luckner, J.L. (2014). Evidence-based practices for students with sensory impairments (Document No. IC-4). Retrieved from: http://ceedar. education.ufl.edu/tools/innovation-configurations/ 
Giraud, T., Therouanne, P., \& Steiner (2018). Web accessibility: Filtering redundant and irrelevant information improves website usability for blind users. International Journal of Human - Computer Studies, 111, 23-35.

Godfrey, A.J.R., Loots, M.T. (2015). Advice from blind teachers on how to teach statistics to blind students. Journal of Statistics Education 23(3), 1-28.

Harshman, J., Bretz, S., \& Yezierski, E. (2013). Seeing chemistry through the eyes of the blind: A case study examining multiple gas law representations. Journal of Chemical Education, 9o(6), 93-103.

Herzberg, T. (2010). Error analysis of brailled instructional materials produced by public school personnel in Texas. Journal of Visual Impairment \& Blindness, 104(12), 765-774.

Holbrook, M.C., \& MacCuspie, P.A. (2010). The Unified English Braille code: Examination by science, mathematics, and computer science technical expert braille readers. $b, 104,533-541$.

Hong, S. (2012). An alternative option to dedicated braille notetakers for people with visual impairments: Universal technology for better access. Journal of Visual Impairment and Blindness (6), 650-655.

Hume, D. (2011). Assistive technology use by Kentucky students with visual impairments. Electronic Theses and Dissertations. Paper 651. Retrieved from: https:// doi.org/10.18297/etd/651.

Jones, B.A., Rudinger, B., Williams, N., \& Witcher, S. (2019) Training general educators in assistive technology competencies for students with visual impairments. British Journal of Visual Impairment, 37(1), 29-39.

Kamei-Hannan, C., \& Lawson, H. (2012). Impact of a Braille-Note on writing: Evaluating the process, quality and attitudes of three students who are visually impaired. Journal of Special Education Technology, 27(3), 1-14.

Kapperman, G., Kelly, S., \& Koster, E. (2018). Using the JAWS screen reader and the Focus braille display to read foreign language books. 112(4), 415-419.

Kelly, S.M., \& Kapperman, G. (2018). A second look at what high school students who are blind should know about technology. Journal on Technology for Persons with Disabilities, 384-397.

Kim, H.K., Han, S.H., Park, J., \& Park, J. (2016). The interaction experiences of visually impaired people with assistive technology: A case study of smartphones. International Journal of Industrial Ergonomics, 55(C), 22-33.

Lazar, J. (2019). The use of screen reader accommodations by blind students in standardized testing: A legal and socio-technical framework. The Journal of Law and Education, 48(2), 185-213.

Lazar, J., Allen, A., Kleinman, J., \& Malarkey, C. (2007). What frustrates screen reader users on the web: A study of 100 blind users. International Journal of Human-Computer Interaction, 22(3), 247-269. 
Leporini, B., Buzzi, M.C., Buzzi, M. (2012, November). Interacting with mobile devices via VoiceOver: Usability and accessibility issues. Proceedings of the 24th Australian Computer-Human Interaction Conference. Melbourne, Australia.

McCarthy, T., Pal, J., \& Cutrell, E. (2013). The 'voice' has it: Screen reader adoption and switching behavior among vision impaired persons in India. Assistive Technology, 25(4), 222-229.

Rudinger, B. (2020). Beyond access: Self-determination, technology, \& blindness. Doctoral dissertation, University of Wisconsin-Stevens Point, Stevens Point, Wisconsin. Retrieved from: https://minds.wisconsin.edu/handle/1793/80185.

Sahib, N., Tombros, A., \& Stockman, T. (2012). A comparative analysis of the information-seeking behavior of visually impaired and sighted searchers. Journal of the American Society for Information Science and Technology, 63(2), 377-391.

Shinohara, K., \& Tenenberg, J. (2009). A blind person's interactions with technology. Communications of the ACM, 52(8), 58-66.

Siu, Y. (2015). A Virtual Water Cooler: The ecology of an online community of practice to support teachers' informal learning. Doctoral dissertation, University of California-Berkley. Retrieved from: https://escholarship.org/uc/item/9x76q5cd.

Siu, Y.T., \& Emerson, R.W. (2017). Redefining roles of vision professionals in education and rehabilitation. Journal of Visual Impairment \& Blindness, 111(6), 593-597.

Smith, D., Kelley, P., Maushak, N., Griffin-Shirley, N., \& Lan, W. (2009). Assistive technology competencies for teachers of students with visual impairments. Journal Of Visual Impairment \& Blindness, 103(8), 457-469.

WebAIM (2017, December 17) Screen reader survey 7 . Retrieved from: https://webaim.org/projects/screenreadersurvey7/

WebAIM (2019, September 27) Screen reader survey 8. Retrieved from: https:// webaim.org/projects/screenreadersurvey8/

Zhou, L., Parker, A.T., Smith, D.W., Griffin-Shirley, N. (2011). Assistive technology for students with visual impairments: Challenges and needs in teachers' preparation programs and practice. Journal of Visual Impairment \& Blindness, 105(4), 197-210.

Zhou, L., Ajuwon, P.M., Smith, D.W., Griffin-Shirley, N., Parker, A.T., \& Okungu, P. (2012). Assistive Technology Competencies for Teachers of Students with Visual Impairments: A National Study. Journal of Visual Impairment \& Blindness, 106(10), 656-665.

\section{BEZWZROKOWY DOSTĘP DO DRUKU I TRUDNOŚCI Z TYM ZWIĄZANE. ANALIZA LITERATURY PRZEDMIOTU}

Streszczenie: W niniejszym artykule przeanalizowano w świetle literatury przedmiotu bariery osób niewidomych w bezwzrokowym dostępie do druku. Autorka przedstawiła dogłębną retrospekcję badań nad zagadnieniami dotyczącymi czytników ekranu i monitorów 
brajlowskich. Wyodrębnione przez nią bariery obejmują złożoność związaną z konwersją druku na alternatywne media (dotykowe i słuchowe), szkolenie z zakresu technologii wspomagających i gotowość tyflopedagogów, a także brak badań nad dobrymi praktykami instruktażowymi oraz szereg zagadnień związanych z ograniczeniami technologii w obszarach dostępności, użyteczności i doświadczenia użytkownika. W zakończeniu sformułowano zalecenia dotyczące praktyki i przyszłych badań w dziedzinie czytników ekranu oraz monitorów brajlowskich.

Słowa kluczowe: technologia wspomagająca; dostęp; niewidomy; użyteczność; wrażenia użytkownika; brajl; zaburzenia widzenia; czytnik ekranu; wyświetlacz brajlowski. 